N. B. Kirillova, O. N. Tomyuk, M. A. Dyachkova

\title{
Educational segment of modern media market: features and trends in digitalization
}

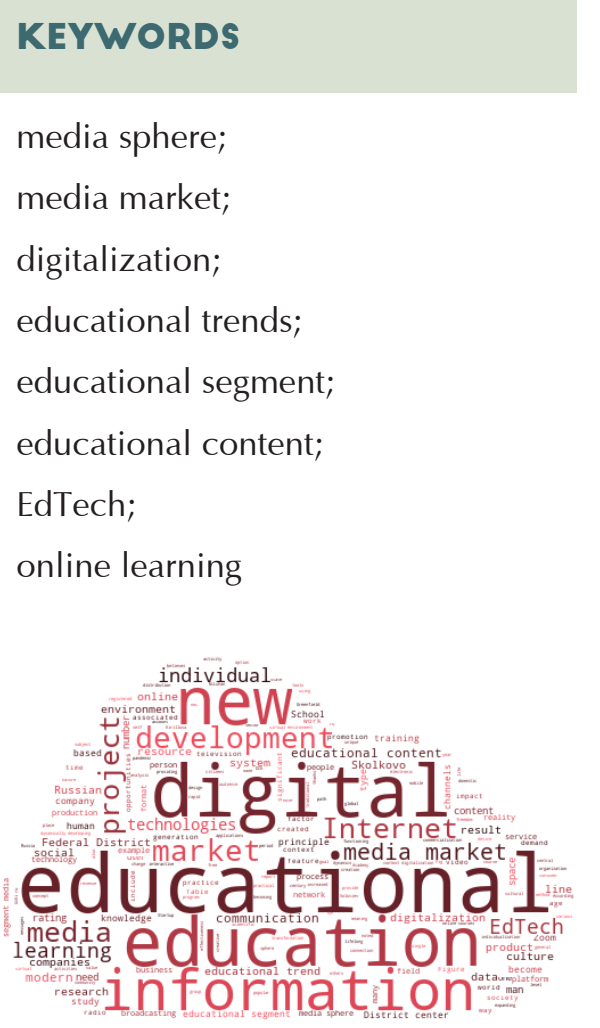

Word Cloud Generated by:

https://wordscloud.pythonanywhere.com/

\section{ABSTRACT}

Introduction. The relevance of the study is due to increased efficiency and accessibility of education in the context of digitalization.

Materials and methods. In the research process, general and special methods of scientific knowledge were used: systemic, structural and functional analysis, expert assessments, analysis and comparison of statistical data obtained as a result of studying the media market.

Results and discussion. The main feature of the media market is that the actors in the media market are firms, individuals involved in the production and promotion of media content, i.e. text messages, audio, video messages, infographics and other types of content. The emphasis in the study is on the modern media market, changing under the influence of a new generation of digital technologies. It is proved that the value of digital transformation for consumers of educational content is associated with the ability to meet individual educational needs, build individual educational trajectories. Analyzed are data on monitoring the effectiveness of economic activity of EdTech companies offering educational content and working in the field of its promotion. The educational trends in the educational segment of the media market and the factors affecting their promotion are identified.

Conclusions. The study allowed concluding that there is a high demand among users of digital, accessible and high-quality educational content for all levels of education from different fields of knowledge

Kirillova, N. B., Tomyuk, O. N., \& Dyachkova, M. A. Educational segment of modern media market: features and trends in digitalization. Economic consultant, 30 (2), 48-61. doi: 10.46224/ ecoc.2020.2.5 


\section{INTRODUCTION}

$\mathrm{T}$ he modern world, becoming a digital civilization, is "a type of development of society, in which the analogue and linear formats of communication and the functioning of systems are replaced by digital, electronic, which determine not only the nature and direction of human and social activities but become the main ones, determining goals and the meanings of human life and activity" [2, p. 519].

Society integrates a variety of socio-cultural phenomena with an angle of refraction through the prism of digitalization [24]. The figure as a key, universal position, in the context of globalization, is put on a par with other "cultural fields" - the alphabet, account, print, Internet. In this regard, the new - the digital equivalent, like the others, is a way that allows fixing the world of culture [1].

Understanding of digitalization in conjunction with new educational practices in all spheres of human being that arose in connection with dynamically developing information technologies is typical for many researchers [25]. Digitalization is woven into the being of man, constructing a new, virtual environment, exerting a transformative effect on the vital activity of modern man.

O. S. Dovbysh defines the media market as "the totality of actors (firms or individuals) involved in the production, packaging or distribution of media content" [7]. O. S. Drobysh calls content as a distinctive feature of the media market in comparison with other business markets. Media, depending on the context, includes various types of data, not only text messages, but also audio and video messages, infographics.

Features of the media product affect the organization of the production process and the configuration of the media market. So, if a single product is based on unique individual content, for the creation of which a specific team is created, then the same type of content requires an organized process, which, as a result, involves different business strategies.

The media market has changed in the context of digitalization. The digital transformation of the market is stated in the report of the SKOLKOVO Business School Research Institute for Emerging Markets (2017): "a new generation of digital technologies creates a new level of consumer value by a previously unattainable combination of accessibility and customization, with the delivery of analytically customized goods and services on demand and often at a much more attractive price compared to the traditional offer" [11]. The report noted the features of the "digitized" consumers: awareness, knowledge of the tools of "cost-free switching between suppliers" of goods and services. The report notes that "the key value of digital transformation is for consumers: cheaper goods and services, offered taking into account individual needs and tasks and delivered where they are needed, and at that moment in time when they are needed [11]. These features give consumers "market power", transforming "market competition", SKOLKOVO analysts consider. 


\section{MATERIALS AND RESEARCH METHODS}

In the research process, general and special methods of scientific knowledge are used: system, structural and functional analysis, expert assessments, analysis and comparison of statistical data obtained as a result of studying the media market and its educational segment.

\section{ANALYSIS OF THE LITERATURE}

Modern scientific research touches on many problems associated with the digital age. The emergence of the Internet, virtual reality technologies, the prediction of their development and their place in the life of people back in the 60s of the 20th century was described in the works of M. McLuhan, S. Lem, M. Castells and other scientists. M. McLuhan from the first thesis "after watching television, a little mouse attacks an adult cat" (previously it was the other way around) and to the last proves that the world is changing [19]. If for three thousand years based on mechanical technologies the world underwent only fragmentary changes, then now, M. McLuhan wrote in the book "Understanding Media: External Extensions of Man" (1964), the outlines of a new era with expanding opportunities for humans are visible [19]. S. Lem, in his Sum of Technology (1963) writes about a virtualized society [18]. F. Hammit believes that the future lies with virtual reality [10, p. 112]. Moreover, M. Castells, exploring the network space, expressed the idea that "the Internet was created as a means of free global communication" [4, p. 5].

The Internet, as a new substance created by man, represents unlimited educational opportunities for the man himself.

The rapid change of information educational technologies, one technological solution to another, increasing information flows, erasing time and space boundaries, the emergence of new educational trends are becoming a significant research problem in foreign and domestic science. G. Jenkins (Massachusetts Institute of Technology) as applied to the community, communicating in a virtual environment, introduces the term "culture of participation", the essence of which consists of a combination of four components - expression (new ways of expressing emotions), collaboration (teamwork), translation (information flow), affiliation (communication in the community) [12, p. 3].

In the works of N. B. Kirillova, the information age is considered in conjunction with the global media environment, when the established "information industry" has an impact on all spheres of life [15]. The current level of cultural development is determined by how electronic they operate with the concepts of "electronic culture" (M. Schwarz [23], K. Weltmann [30] and others), "virtual reality" (J. Lanier [17] and others), talk about the impact of digitalization on the meanings of being [3].

Digitalization is woven into education, constructing a new, virtual environment, having a transformative effect on the way education is received. Information technology is becoming 
the backbone of On-line education. New digital ways of transmitting information not only provided people with interactive communications but also created a virtual environment for satisfying educational needs.

N. B. Kirillova, justifying the creative nature of the media sphere in the context of the formation of "Homo medium", identifies many essential aspects: the "subject-object" nature of the relationship in the system of "man-media reality-society" through the concepts of "influence", "impact"; the media environment is a resource of directed socialization and, at the same time, free self-determination with learning opportunities, the satisfaction of leisure needs.

V. S. Stepin, L. F. Kuznetsova, comparing the value systems of traditional and technogenic cultures, revealed the dominants of modern culture - freedom of choice, variability, individualization, expanding opportunities for the development of individual creative principles in a person [26]. Researchers emphasize that the digital environment is a factor in the development of the individuality of modern man.

Anthropocultural practice, meaning individualization, is defined through the concepts of "individual trajectory", "individual route". The Internet-space in this context acts as a unique environment with the potential to design an individual strategy for transforming being as a whole and being of a person. T. M. Kovaleva names three interconnected action vectors that provide an individual strategy in the context of individualization: vector $X$ - social (using the resources of society), $Y$ - subject (immersion in the field of knowledge of interest), $Z$ anthropological (improving oneself) [16]. In the digital environment, the education process is personality-oriented, has an impact on human behaviour, the formation of its "I" concept, and is a motivational space, an environment of great opportunities and self-realization.

Information technologies rapidly bursting into life have updated new vectors in the study of education, namely, the study of transformations in education, new educational practices that have become a reality in the context of digitalization. Digitalization has enriched education with new phenomena: "Digital Humanities" as a field of humanitarian knowledge using IT (for example, digital humanities, computer linguistics); "Art \& Science" as an "interactive semantic space" with network communications in scientific and educational environments, for example, On-line. Digitalization with new educational practices and educational environments necessarily requires a person to own a dynamically developing new ICT toolkit, to be included in the process of continuing education.

D. Tapscott calls the generation of people born in the period from the 90s. XX century and later, "Net Generation" [27]. L. Rosen, based on a study of the features of the new generation, suggests using the term "iGeneration" to designate a modern person, wherein "i" is the type of digital technology popular with a modern person (iPhone, iPod, iTunes) and individualized types of activities that become possible thanks to these technologies [22]. An illustration is the data of the All-Russian representative poll of the All-Russian Public Opinion Research Center "People in Digital: The Age of Post-Truth" (information as of November 24-25, 2018): 84\% of Russians are Internet users, $66 \%$ of them use the Internet daily, $62 \%$ - users of social networks, $95 \%$ of the entire young population aged 18 to 24 years - users of social networks, access to 
which $88 \%$ of young people through a mobile phone/smartphone. According to the results of the VTsIOM study, the conclusions were drawn: "The Internet is increasingly having a real and quite tangible impact on everyday life." Thus, the Internet, digital technologies and devices have become new cultural and historical tools that mediate the activities and communications of modern man. For a person of "i" generation, everyday life is connected with a number, now, L. Rosen believes, one must "take advantage" of their love for technology and reorient education, coordinating it with individual human needs [22].

The Internet, as a phenomenon of digital culture, is multifunctional. N. B. Kirillova singles out as one of the essential functions singles out the economic function associated with commercialization, the effectiveness of information technologies and products [13, p. 219-220].

\section{RESEARCH RESULTS AND DISCUSSION}

The media market is quite impressive. As far back as the 1990s, radical structural and functional changes took place in the domestic television and radio broadcasting, associated with the commercialization of the media sphere, which becomes an element of the market system, subject to the laws of its functioning [13]. The logic of the process of commercialization of the media sphere is as follows: the accumulation of functioning media structures, the buildup of material, financial, intellectual resources necessary for the production and distribution of content. So, at the beginning of the XXI century, such media holdings as VGTRK (channels "Russia", "Culture", central radio stations "Radio of Russia", "Mayak", "Youth", "Orpheus", international broadcasting and 92 regional state television and radio companies were formed), Gazprommedia group (NTV, NTV + channels and other channels). If we characterize the modern media market, we can note its dynamics, caused in particular by the rapid development of the Internet, the advent of digital broadcasting channels, electronic publications (Table 1, Fig. 1).

Table 1

Public register of the broadcasting infrastructure of the Russian Federation (sample based on data from the central cities of the Federal Districts as of June 2020) [29]

\begin{tabular}{|l|c|c|c|c|c|}
\hline \multirow{2}{*}{ Name of the Federal District (FD) } & \multicolumn{2}{|c|}{ Radio broadcasting } & \multicolumn{2}{|c|}{ Television broadcasting } & $\begin{array}{c}\text { Broadcast } \\
\text { Cable }\end{array}$ \\
\cline { 2 - 5 } & $\begin{array}{c}\text { number of } \\
\text { DCh* }\end{array}$ & $\begin{array}{c}\text { number of } \\
\text { ACh** }\end{array}$ & $\begin{array}{c}\text { number of } \\
\text { DCh* }\end{array}$ & $\begin{array}{c}\text { number of } \\
\text { ACh** }\end{array}$ & $\begin{array}{c}\text { CTV*** } \\
\text { number of } \\
\text { channels }\end{array}$ \\
\hline $\begin{array}{l}\text { Central Federal District (center - } \\
\text { Moscow) }\end{array}$ & 63 & 79 & 672 & 10 & 6697 \\
\hline $\begin{array}{l}\text { North-West Federal District (center }- \\
\text { St. Petersburg) }\end{array}$ & 3 & 69 & 680 & 13 & 4350 \\
\hline $\begin{array}{l}\text { Southern Federal District (center }- \\
\text { Rostov-on-Don) }\end{array}$ & 3 & 20 & 20 & 16 & 845 \\
\hline
\end{tabular}




\begin{tabular}{|l|c|c|c|c|c|}
\hline $\begin{array}{l}\text { North Caucasian Federal District } \\
\text { (center - Pyatigorsk) }\end{array}$ & 3 & 21 & 20 & 15 & 493 \\
\hline $\begin{array}{l}\text { Volga Federal District (center - Nizhny } \\
\text { Novgorod) }\end{array}$ & 3 & 33 & 20 & 11 & 1314 \\
\hline $\begin{array}{l}\text { Ural Federal District (center - } \\
\text { Ekaterinburg) }\end{array}$ & 3 & 40 & 20 & 8 & 2354 \\
\hline $\begin{array}{l}\text { Siberian Federal District (center - } \\
\text { Novosibirsk) }\end{array}$ & 3 & 29 & 20 & 13 & 637 \\
\hline $\begin{array}{l}\text { Far Eastern Federal District (center - } \\
\text { Vladivostok) }\end{array}$ & 3 & 14 & 1132 & 6 & 973 \\
\hline
\end{tabular}

* DCh - digital channels.

** ACh - analog channels.

*** CTV - cable television.

Figure 1 shows the distribution of registered media by type based on data from the Federal Service for Supervision of Communications, Information Technologies and Mass Communications, which, in accordance with the Federal Law "On Mass Media" [28], maintains a unified all-Russian register of registered media [6].

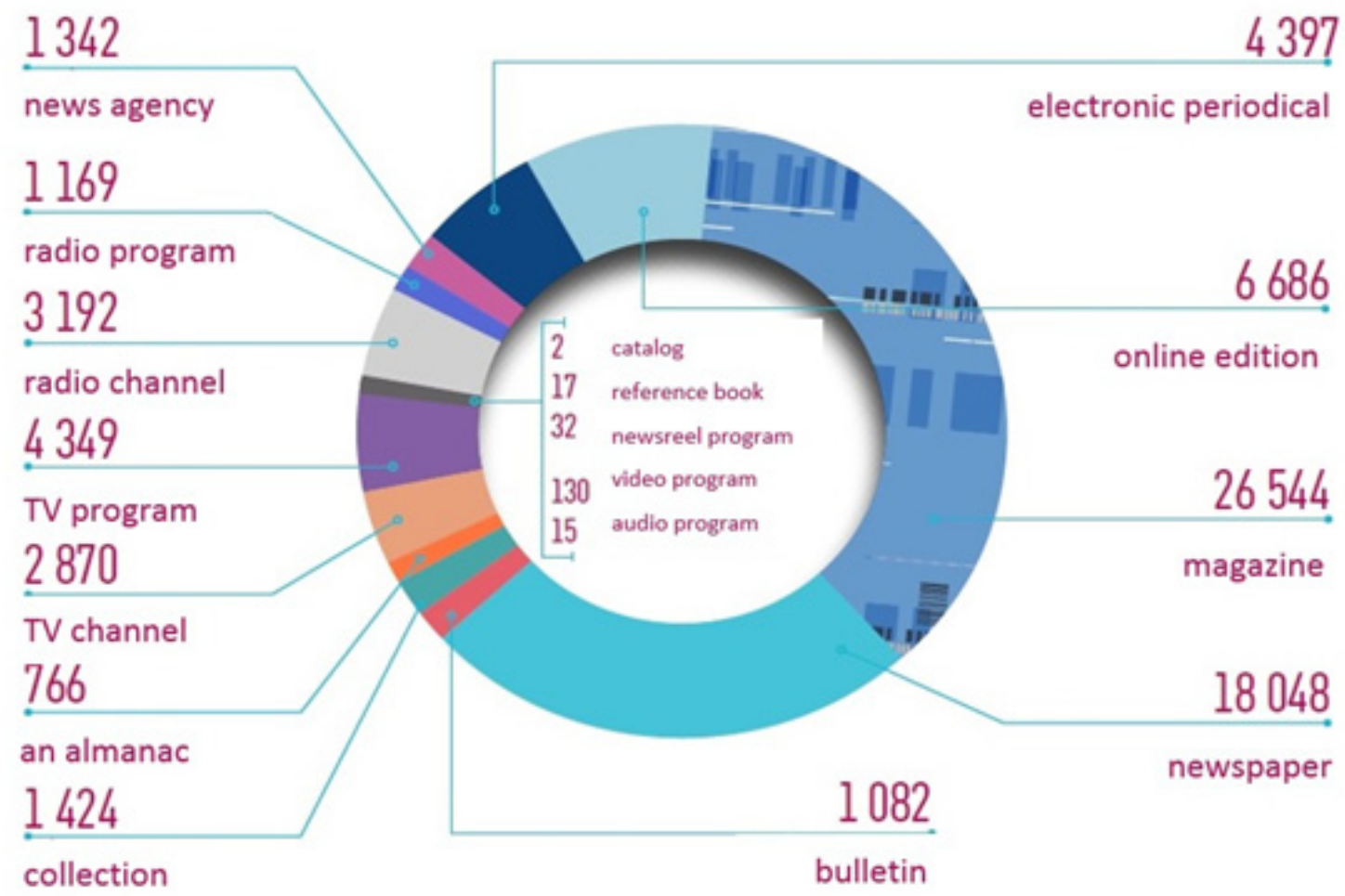

Figure 1 Distribution of registered media by type (2018)

Educational content is being promoted in all media, new media. In the field of education, due to the wave of technological innovations, a new space of new educational initiatives and educational projects (educational startups) that are created from scratch is being formed. Such educational projects were called "Greenfield", which refers to the meaning of the English word "greenfield" - a project that does not have any restrictions imposed by the previous work. "Greenfield" in education is not a mastered space where it is entirely comfortable, without adjusting to the existing contours, projects that have received the unique name "EdTech" are being mastered. 
In the educational services market, both state and private companies act as subjects. Many rating agencies monitor and analyze the effectiveness of the economic activities of companies offering educational content. Let us analyze the results of the rating of private Russian EdTech companies according to the results of 2018, presented by the media holding RosBusinessConsulting (after this - RBC) [31]. The rating was prepared by A. Basov (RBC), D. Karakash (IIDF), A. Soloviev (Skolkovo Digital), D. Starikov (cluster of the Skolkovo IT Foundation), N. Tsarevskaya-Dyakina (EdTech-accelerator Ed2).

The largest Russian companies EdTech (companies of technological educational projects) were included in the rating. In contrast, the position in the rating was determined by the size of revenue for the year. It should be noted that the rating did not include international projects, projects of state organizations and universities for which EdTech is an applied activity (for example, the Open Education platform).

Table 2

The largest EdTech companies in Russia: RBC rating (company data, Contour Focus systems, open sources, 2018) [31]

\begin{tabular}{|c|l|l|}
\hline No & \multicolumn{1}{|c|}{ Name of company } & \\
\hline 1 & Skyeng & P 1100 million \\
\hline 2 & «Netologiya-group» & P 780 million \\
\hline 3 & iSpring & P627 million \\
\hline 4 & MAXIMUM Edukation & P600 million \\
\hline 5 & «Umney» ("Smarter") & P560 million \\
\hline 6 & SkillBox & P540 million \\
\hline 7 & «UCHi.RU» & P500 million \\
\hline 8 & «Dnevnic.ru» & P500 million \\
\hline 9 & GeekBrains & P480 million \\
\hline 10 & «GetCourse» & P420 million \\
\hline 11 & «Mirapolis» & P368 million \\
\hline 12 & «Your tutor» & P300 million \\
\hline 13 & «Info-lesson» & P246 million \\
\hline 14 & City Business School & P207 million \\
\hline 15 & Lingualeo & P200 million \\
\hline 16 & InternetUrok & P175 million \\
\hline 17 & Company group Puzlle Englich & P170 million \\
\hline 18 & Easy Ten & P150 million \\
\hline 19 & Sikorsky Academy & P145 million \\
\hline 20 & «Algoritmica» & P143 million \\
\hline 21 & «Vikium» & P135 million \\
\hline 22 & eQueo & P130 million \\
\hline 23 & «Universarium» & P120 million \\
\hline 24 & EnglishDom & P110 million \\
\hline 25 & HTML Academy & P101 million \\
\hline 26 & YaClass & P100 million \\
\hline & & \\
\hline
\end{tabular}




\begin{tabular}{|l|l|l|}
\hline 27 & Inlearno & P95 million \\
\hline 28 & Teachbase & P95 million \\
\hline 29 & Skill Cup & P94 million \\
\hline 30 & «Netrica» & P89 million \\
\hline 31 & Otus & P80 million \\
\hline 32 & FROO & P74 million \\
\hline 33 & Uniweb JetSkills JetSpeak LiveCV JetTrack & P70 million \\
\hline 34 & SkillFactory & P61 million \\
\hline 35 & Eduson & P60 million \\
\hline
\end{tabular}

EdTech consists of many segments; namely, the system projects Uchi.ru, Diary.ru, Infourok, YaClass and others; P2P training, online lessons, applications, training content that attracts and holds the audience in the face of intense competition. Many Russian companies in the EdTech sector are successfully operating on the Russian market (Table 2). Based on the rating data, it can be concluded that users of educational media products need affordable and high-quality educational content for all levels of education and in different fields of knowledge, and the EdTech market, in turn, is an actively developing segment of the media market.

It should be noted that the Moscow School of Management SKOLKOVO is a serious participant in the educational services market, actively working to promote the range of educational programs (for example, Executive coaching; LIVE Startup Academy; School of Rectors; School development step; Startup Academy Junior; Career navigator Junior LIVE and other programs) taking into account existing needs and built on the principle of "learning through action" [8]. According to analysts, educational projects are promising, since most of them are financed from the proceeds from sales.

The educational segment of the media market in the context of digitalization is a dynamically developing market with pronounced educational trends. Consider the fundamental educational trends of the modern media market N. Tsarevskaya-Dyakina believes that digitalization has served as an important factor in the development of educational trends such as online learning, individualization, tutoring, mentoring, "lifelong learning" [31]. D. Karakash (IIDF) identifies commercial lines that are more promising on the EdTech market, such as the development of system projects (Uchi.ru, Diary.ru and other projects), online courses in creative specialities, gamification and neuro device applications, in which reflects the global educational trend, manifested in the dominance of entertainment educational content - "entertainment", which attracts and retains an audience in a competitive environment in the educational segment of the media market [31]. A. Basov (RBC) speaks of digitalization as a factor in increasing the effectiveness and accessibility of education, including "the creation of educational content, services for selecting educational programs, educational aggregator platforms, solutions for managing personal, educational paths and knowledge verification technologies" [31]. D. Starikov (Skolkovo) provides the following data: thanks to EdTech Skolkovo projects, the target audience increased by 50\% over the year; EdTech Skolkovo projects in 2021 can close $80 \%$ of the domestic online education market; such large companies as Sberbank and Yandex are unfolding in the educational segment of the media market, which is projected to capture 
a significant market share; the appearance of popular startups in preschool, general and additional education of children and adults; the need for personalized content and technological solutions for its selection [31]. A. Soloviev (Skolkovo Digital venture partner) emphasizes the rapid growth of EdTech: 2017 - EdTech is not in the top ten investment segments, 2018 - the educational segment entered the TOP-5 segments for investment, since there are business models in this segment, for example, an online school [31]. Online education, and, along with it, adaptive blended learning, says A. Soloviev.

Table 3

Educational trends in online learning and factors influencing their promotion

\begin{tabular}{|c|c|}
\hline Educational trend & Factors Affecting Educational Trends \\
\hline Individual learning path & $\begin{array}{l}\text { A request for an individual educational trajectory, a flexible educational } \\
\text { route, an individual educational program. } \\
\text { The development of EdMarket. } \\
\text { The modular structure of the educational product line. }\end{array}$ \\
\hline Lifelong learning & $\begin{array}{l}\text { Production and consumption of educational content for all ages. } \\
\text { Labour market transformation }\end{array}$ \\
\hline Mobile learning & $\begin{array}{l}\text { Development of applications for mobile devices that provide the } \\
\text { opportunity to consume educational products in a convenient place for } \\
\text { the user. }\end{array}$ \\
\hline Online Learning & $\begin{array}{l}\text { Design and promotion of online courses. } \\
\text { A variety of additional options (feedback, course mastery control, } \\
\text { course mastery diagnostics and other options). }\end{array}$ \\
\hline Practical orientation of training & An educational product, such as online case-based courses. \\
\hline Internships and employment & $\begin{array}{l}\text { An educational product, including an internship (practical) module. } \\
\text { Proposals related to the possibility of the practical development of } \\
\text { knowledge and the guarantee of subsequent employment. }\end{array}$ \\
\hline Blended learning & Educational courses that include online and offline training. \\
\hline Multiformat training & $\begin{array}{l}\text { Online courses are offering educational content in the video, audio, test } \\
\text { format and other formats. }\end{array}$ \\
\hline Gamification & Online courses with gaming technology. \\
\hline $\begin{array}{l}\text { The trend towards the creation of } \\
\text { community and networking }\end{array}$ & $\begin{array}{l}\text { An educational product with resources for networking, building } \\
\text { relationships with people to solve various kinds of tasks (social, } \\
\text { professional), and providing mutual assistance. }\end{array}$ \\
\hline
\end{tabular}

D. Evstafiev, L. Tsyganova note that the sociocultural multi-vector becomes a reality of the virtual world [9]. Moreover, it is in education that, first of all, in new and understandable formats, the consequences caused by the pandemic crisis are manifested. In connection with the transition of educational organizations in conditions of social isolation to the distance learning format, all areas of activity are implemented through Internet information resources. The need for the development of digital tools and digital services has grown; practices such as Zoom conferences on-line (remote presence) have gained importance.

McKinsey \& Company has the goal to assist universities in preparing for various work scenarios during the primary campaign. McKinsey \& Company conducted a study of the moods of graduates. As a result, it was found that graduates of schools, despite the expanding On-line 
education, still have higher education in priority [5]. At the same time, the question arises: will classical education continue as a social institution with sustainable social communications? We see a connection between the processes occurring in education in a pandemic and the further development of lifelong education, digital didactics, information educational technologies, the expansion of mixed and distance learning formats at all levels of education.

It is evident that in the context of digitalization, the pandemic as a milestone event not only led to the promotion of educational content thanks to the Internet, On-line digital resources (on-line training, on-line conferences), platforms made it possible to design individual educational strategies, but also increased the demand for EdTech-projects, educational content, as a result, the number of users of the product of the company "Uchi.ru" increased by 50\%, "Pearson" - by 400\% [31].

Here are the results of the research - TOP-5 platforms for video conferencing, conducted by Medialogia, a developer of an automatic system for monitoring and analyzing media and social media in real-time from April 1, 2020, to May 11, 2020 (Fig. 2). The research methodology includes: posting messages on Twitter, VKontakte, Odnoklassniki, Facebook, Instagram, YouTube, Telegram, TikTok, forums and blogs; ranking on the SM Index (in thousand) [20].

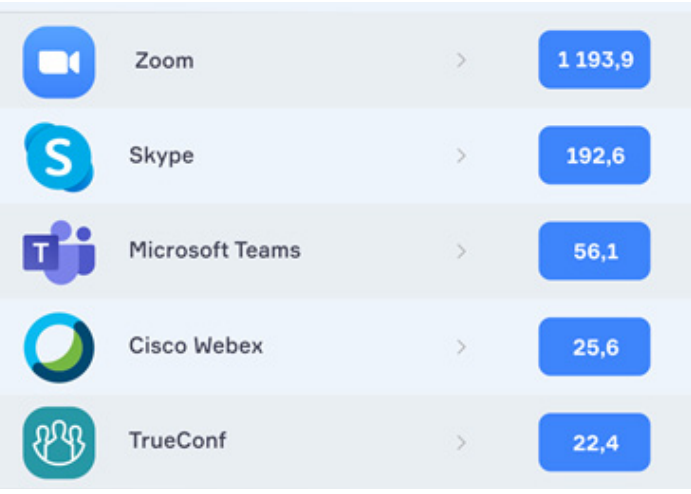

Figure 2 TOP-5 platforms for video conferencing

During the spread of COVID-19 and in connection with the transition of educational organizations to the remote interactive learning mode, digital educational content became more popular, the promotion of which was facilitated by the latest technological solutions, for example, Zoom Video Communications. Zoom turned out to be the most popular and affordable option, as evidenced by the dynamics of Zoom revenue (Fig. 3).

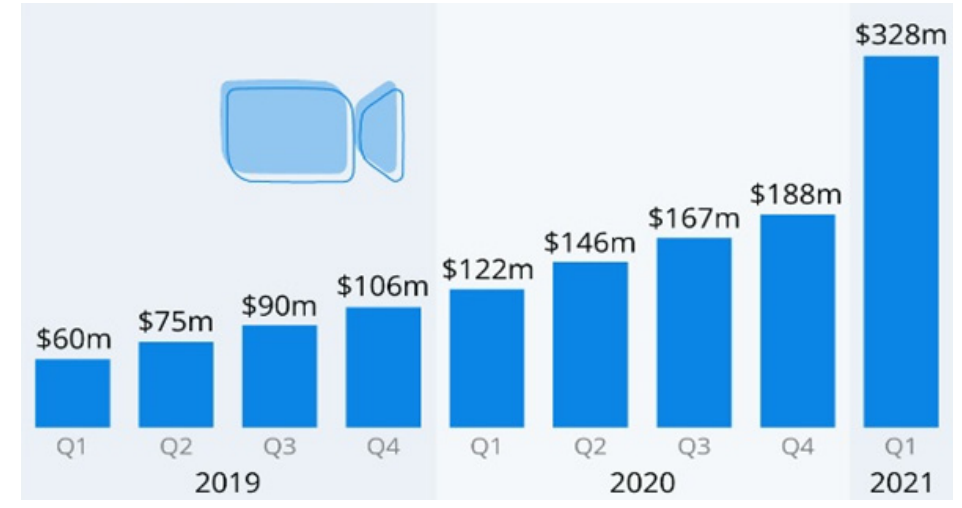

Figure 3 Zoom revenue dynamics for the period from 01.01.2019 to the present (with a forecast for 3-4 Q 2020, 1 Q 2021) 
The dynamics of demand testifies to the high demand for this method of communication, transmission and exchange of information, about the integration of Zoom in to study, work, everyday life. Zoom was especially in demand in the educational segment of the media market. The company's revenue in the indicated period (Fig. 3) will increase by $169 \%$ and amount to $\$ 328 \mathrm{~m}$.

It should be noted that under the current conditions, the experiment on providing data transfer services to citizens and providing access to the Internet information and telecommunication network in the Russian Federation for the use of socially significant information resources in the Internet information and telecommunication network is socially significant. One of the goals of the pilot project for citizens in self-isolation is to ensure comfortable citizens receive free of charge the necessary information. The list of Internet resources includes information resources from the field of "Education and Training" [21].

\section{CONCLUSION}

The active introduction of digital technologies in the media sphere determines its development, which has become an integral part of the media market. The digital development of the media sphere must comply with the principles of digital freedom: the principle of freedom for citizens, the principle of freedom for business, the principle of responsibility, the principle of responding to challenges in the digital sphere. In general, the media market associated with the production and promotion of media content is actively developing, with the educational segment playing a significant role in it. The educational content market covers all traditional media and new media and it is actively developing on all platforms.

The educational segment of the media market in the context of digitalization is a dynamically developing market with pronounced educational trends, one of which is lifelong learning, associated with the production and consumption of educational content for all ages, individual educational paths.

\section{ACKNOWLEDGMENTS}

The reported study was funded by RFBR, project number 20-013-00813 "Educational potential of the media sphere as a space for the development of legal culture and human rights culture in modern Russia". 


\section{REFERENCES}

1. Antipov, A. A. (2018). Cultural and philosophical foundations of digital culture. Man. Society. Inclusion, 2 (34), 37-44 (in Russian).

2. Astafyeva, O. N., Nikonorova, E. V., \& Shlykova, O. V. (2018). Culture in digital civilization: a new stage in understanding the strategy of the future for sustainable development. Observatory of Culture, 5 (15), 519 (in Russian).

3. Astafyeva, O. N., Nikonorova, E. V., \& Shlykova, O. V. (2019). Digital culture: a new stage in the transformation and understanding of the smart future strategy. Information era: new paradigms of culture and education: monograph / N. B. Kirillova (Ed.). Ekaterinburg, Publishing House Ural. University, 2019, 46-68 (in Russian).

4. Castells, M. Galaxy Internet: Reflections on the Internet, business and society / A. Matveeva (Trans.; V. Kharitonova (Ed.). Ekaterinburg, U-Factoria Publ., 2004, 5 (in Russian).

5. Charag, Krishnan, Jonathan, K. Law. COVID-19 and US higher education enrollment: Praparing leaders for fall [Electronic resource]. Retrieved from: https://www. mckinsey.com/industries/social-sector/our-insights/covid-19-and-us-higher-educationenrollment-preparing-leaders-for-fall (Access mode: 21.05.2020).

6. Distribution of registered media by type / Public report of the Federal Service for Supervision of Communications, Information Technologies and Mass Communications. The 2018 year. Moscow, 2019, p. 48 [Electronic resource]. Retrieved from: https://rkn. gov.ru/docs/doc_2406.pdf (Access mode: 06.16 2020) (in Russian).

7. Dovbysh, O. (2015). Media Markets in the Focus of Social Network Analysis. Journal of Economic Sociology = Ekonomicheskaya sotsiologiya, 4 (16), 85-107. Retrieved from: http://ecsoc.hse.ru/2015-16-4.html (in Russian).

8. Educational programs [Electronic resource]. Retrieved from: https://common.skolkovo. ru/ru/educational-programmes/ (Access mode: 15.05.2020) (in Russian).

9. Evstafiev, D., Tsyganova, L. Transformations of social space as a premonition of a new world [Electronic resource]. Retrieved from: https://www.hse.ru/news/community/362878514. html (Access mode: 07.05.2020) (in Russian).

10. Hammet, F. (1993). Virtual Reality. New York, Straus Ed. Publ., 112.

11. How to understand digital transformation? Working paper by the Institute for Emerging Market Research, SKOLKOVO Business School (IEMS). 2017, 34. [Electronic resource]. Retrieved from: https://iems.skolkovo.ru/downloads/documents/SKOLKOVO_IEMS/ Research_Reports/SKOLKOVO_IEMS_Research_2017-05-18_en.pdf (Access mode: 04.04.2020) (in Russian).

12. Jenkins, H., Clinton, K., \& Purushotma, R. etc. (2006). Confronting the Challenges of Participatory Culture: Media Education for the 21st Century, 3.

13. Kirillova, N. B. (2008). Media management as an integrating system. Moscow, Academic project Publ., 412.

14. Kirillova, N. B. (2008). The diversity of cultures in the global media space and the search for a new identity. Media management as an integrating system. Moscow, Academic Project Publ., 51-66 (in Russian). 
15. Kirillova, N. B. (2017). The global media environment as the evolution of media culture. The Paradoxes of Media Civilization: selected articles, Ekaterinburg, Publishing House Ural. Univ., 7-19 (in Russian).

16. Kovaleva, T. M. (2010). Organization of tutoring in a modern school. Problems of modern education, 4, 19-23 (in Russian).

17. Lanier, J. (2012). You Are Not a Gadget. London, Penguin Books, 240.

18. Lem, S. (1964). Summa Technologiae. Krakw, Wydawnictwo Literackie, 501.

19. McLuhan, M. (2003). Understanding Media: External Extensions of Man / V. G. Nikolaev (Trans.). Moscow, Hyperborea; Kuchkovo Field Publ., 464. (in Russian).

20.Medialogy [Electronic resource]. Retrieved from: https://www.mlg.ru/products/smm/ (Access mode: 21.06.2020) (in Russian).

21. Order of the Ministry of Telecom and Mass Communications of Russia No. 148 of 03/31/2020, "On an experiment on providing citizens with free of charge communication services for data transfer and providing access to the information and telecommunication network "Internet" in the Russian Federation to use socially significant information resources in information and telecommunication network "Internet" [Electronic resource]. Access mode: https://digital.gov.ru/ru/documents/7146/ (Access mode: 01.06.2020) (in Russian).

22. Rosen, L. (2007). Teaching the iGeneration. Educational Leadership, 68 (5), 10-15.

23. Schwarz, M. E-Culture: Crossovers and Challenges [Electronic resource]. Retrieved from: http://eculturefactory.de/download/schwarz.pdf (Access mode: 01.04.2020).

24. Smetankina, L. V., \& Shabanov, L. V. (2018). Culture of creativity in the globalization project (socio-philosophical analysis / Creativity as a national element: media and social activity: a collection of articles. St. Petersburg, Publishing House of St. Petersburg State University of Economics, 414-421 (in Russian).

25. Soldatova, G. U., Rasskazova, E. I., Chigarkova, S. V., \& Lvova, E. N. (2018). Digital culture: rules, responsibility and regulation / Digital society as a cultural-historical context of human development: a collection of scientific articles. Kolomna, State Social and Humanitarian University Publ., 374-379 (in Russian).

26. Stepin, V. S., \& Kuznetsova, L. F. (1994). Scientific picture of the world in the culture of technogenic civilization. Moscow, IFRAN Publ., 274 p. (in Russian).

27. Tapscott, D. Growing up digital: The rise of the Net Generation. New York, McGrawHill Publ., 1999.

28. The law of the Russian Federation dated 12.27.1991 No. 2124-1 (as amended on 01.03.2020) "On the media" [Electronic resource]. Retrieved from: http://docs.cntd.ru/ document/9003299 (accessed date: 12.06 2020) (in Russian).

29. The public register of the communications and broadcasting infrastructure of the Russian Federation [Electronic resource]. Retrieved from: http://reestr-svyaz.rkn.gov.ru/ (Access mode: 12.06.2020) (in Russian).

30. Veltmann, K. (2002). Electronic culture: achievements and prospects. Information Society, 1, 24-30 (in Russian).

31. Largest EdTech companies in Russia: $R B C$ rating [Electronic resource]. Retrieved from: https://trends.rbc.ru/trends/education/5d68e8fb9a7947360f1e2e52 (Access mode: 03.05.2020) (in Russian). 


\section{INFORMATION ABOUT THE AUTHORS}

1. Natalia B. Kirillova (Russia, Ekaterinburg) - Professor, Doctor of Culturology, Head of the Department of Culturology and socio-cultural activities, Department of Art, Culturology and Design . Ural Federal University named after the first President of Russia B. N. Yeltsin. E-mail: n.b.kirillova@urfu.ru. Scopus ID: 57215900537

2. Olga N. Tomyuk (Russia, Ekaterinburg) - Senior Lecturer, Department of Ontology and Theory of Knowledge, Department of Philosophy. Ural Federal University named after the first President of Russia B.N. Yeltsin. E-mail: olga.tomyuk@urfu.ru. Scopus ID: 57211983935

3. Margarita A. Dyachkova (Russia, Ekaterinburg) - Associate Professor, PhD in Pedagogical Sciences, Associate Professor of the Department of Art Education. Ural State Pedagogical University. E-mail: dyachkova.margarita@yandex.ru. Scopus ID: 57211982998 